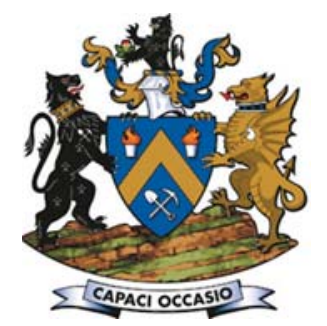

\title{
Evaluation of ozonation technology for gold recovery and cyanide management during processing of a double refractory gold ore
}

\author{
by V. Bazhko* and V. Yahorava*
}

\section{Synopsis}

The depletion of conventional gold resources around the world has resulted in mining companies and research institutions exploring the recovery of gold from refractory and double refractory ores. However, conventional gold processing routes are not feasible for such deposits due to the low gold recoveries and higher reagent consumptions. A number of technologies have been developed to overcome refractoriness, one of which is ozonation. The unique chemical properties of ozone have been tested successfully on a laboratory scale for the pre-oxidation of refractory ores as well as for the detoxification of cyanide effluent streams. However, ozonation has never been implemented on a commercial scale due to the high capital and operating costs associated with ozone generation. Recent developments in ozone generation and contactor systems have revived interest in ozonation as a technology for the processing of refractory ores and the recycling and detoxification of cyanide streams.

In order to demonstrate the viability of these new developments and to evaluate their impact on the entire cyanide management cycle, it is important to quantify the performance of ozonation technology on a double refractory ore. The effect of $\mathrm{pH}$ on sulphide, cyanide, and thiocyanate oxidation as well as the decomposition of the preg-robbing component was evaluated. Pre-oxidation of the material with ozone in an acidic medium ( $\mathrm{pH} 1-2)$ resulted in the oxidation of sulphides and the liberation of gold. Partial destruction of the preg-robbing component was also observed. This resulted in increased gold recoveries during the subsequent cyanidation step. It was also established that ozone in an alkaline medium can oxidize more than $99 \%$ of $\mathrm{CN}^{-}$and $\mathrm{SCN}^{-}$within 30 minutes. Moreover, ozonation was found to be efficient for treatment of both filtrates and slurries. In an acidic medium $(\mathrm{pH} 2), 60 \%$ of the thiocyanate was converted to cyanide. This reaction can potentially be utilized for cyanide regeneration from thiocyanate formed during cyanidation of sulphide minerals.

It is thus concluded that ozonation could be incorporated at different stages of gold processing in order to improve gold recovery, reduce operating costs by recycling cyanide, and minimize the environmental impact by efficient detoxification of the effluent streams.

Keywords

refractory gold, gold recovery, pre-oxidation, ozonation, cyanide detoxification. presence of sulphides can affect gold recovery via cyanidation due to encapsulation or passivation of the gold, thereby increasing reagent consumption. In the case of double refractory ores, gold recovery is further limited due to the presence of carbonaceous materials as well as sulphides. Carbonaceous material can encapsulate and/or adsorb gold from cyanide solution, thus competing with activated carbon added (the so-called pregrobbing effect).

A number of approaches have been developed for the treatment of refractory/double refractory gold ores. In order to overcome refractoriness associated with sulphides the partial or complete destruction of sulphides (and sometimes carbon) via chemical or biological processes, pressure oxidation, or roasting is typically considered. In the case of refractoriness associated with carbonaceous material, resin-in-pulp (RIP) technology, sometimes with the addition of blinding reagents, is used or alternative lixiviants to cyanide are applied.

Ozone can potentially be utilized for preoxidation of refractory ores, thus improving gold recovery and lowering subsequent cyanide consumption. The unique chemical properties of ozone can also potentially be utilized at other stages of gold processing. Ozone can be used for the destruction of free and weak acid dissociable (WAD) cyanide, thiocyanate (SCN), and (partially) strong acid dissociable (SAD) cyanide. Ozone has also been found to show potential for cyanide regeneration from thiocyanate formed during cyanidation of sulphur-containing materials (Botz, 2001).

The current paper presents results from a study conducted to evaluate ozonation

* Mintek, Randburg, South Africa.

(C) The Southern African Institute of Mining and Metallurgy, 2017. ISSN 2225-6253. This paper was first presented at the Hydrometallurgy Conference 2016 'Sustainable Hydrometallurgical Extraction of Metals', 1-3 August 2016, Belmont Mount Nelson Hotel, Cape Town. 


\section{Evaluation of ozonation technology for gold recovery and cyanide management}

technology for processing of a South African double refractory ore sample which yields a low gold recovery via conventional cyanidation.

\section{Background theory}

Ozone is a powerful oxidant with a high standard oxidation potential in both acidic and alkaline media (Lurje, 1971):

$$
\begin{array}{ll}
\mathrm{O}_{3}+2 \mathrm{H}^{+}+2 \mathrm{e}^{-} \rightarrow \mathrm{H}_{2} \mathrm{O}^{-}+\mathrm{O}_{2} & \mathrm{E}^{0}=2.07 \mathrm{~V} \\
\mathrm{O}_{3}+\mathrm{H}_{2} \mathrm{O}-2 \mathrm{e}^{-} \rightarrow 2 \mathrm{OH}^{-}+\mathrm{O}_{2} & \mathrm{E}^{0}=1.24 \mathrm{~V}
\end{array}
$$

and which readily reacts with species containing multiple bonds such as $\mathrm{C}=\mathrm{C}, \mathrm{C}=\mathrm{N}$, and $\mathrm{N}=\mathrm{N}$, as well as. ions such as $\mathrm{S}^{2-}$ with the formation of $\mathrm{SO}_{4}{ }^{2-}$ ions.

Ozone has a limited solubility in water, which depends on a number of parameters such as ozone concentration in the gas phase, temperature, and $\mathrm{pH}$. Henry's Law describes the linear correlation between the concentration of ozone in the gas $\left.\left(\mathrm{O}_{3 \mathrm{~g}}\right)\right)$ and aqueous $\left(\mathrm{O}_{3 \mathrm{~s}}\right)$ phases (Lenntech, 1998):

$\mathrm{Hc}=\mathrm{O}_{3 \mathrm{~g}} / \mathrm{O}_{3 \mathrm{~s}}$

The Henry's Law constant (Hc) is a function of temperature, $\mathrm{pH}$, and ionic strength of the liquid phase.

The negative effect of temperature on ozone solubility in 'pure' water is described by Equation [4] (Bin, 2006):

$$
\mathrm{H}_{\mathrm{c}}=\mathrm{a} \exp (b t)
$$

where $\quad a=1.599 \pm 0.0164$

$\mathrm{b}=0.0473 \pm 0.0004$ in the temperature range from 0 to $60^{\circ} \mathrm{C}$

$t$ is temperature in ${ }^{\circ} \mathrm{C}$.

An increase in $\mathrm{pH}$ value and ionic strength generally decreases ozone solubility, as shown in Figure 1 and Figure 2 , respectively.

Ozone reacts with hydroxyl ions via multiple steps involving the formation of ${ }^{\circ} \mathrm{OH},{ }^{\circ} \mathrm{O}_{2}{ }^{-},{ }^{\circ} \mathrm{O}_{3}{ }^{-}$and $\mathrm{HO}_{2}{ }^{\circ}$ radicals. The depletion is a chain process and has been described by different mechanisms (Ershov, 2009; Langlais, 1991).

At high $\mathrm{pH}$ values, the ozone decomposition rate is essential as shown in Figure 3.

If easily oxidized compounds are present in water, larger amounts of ozone will dissolve to satisfy the demand. A

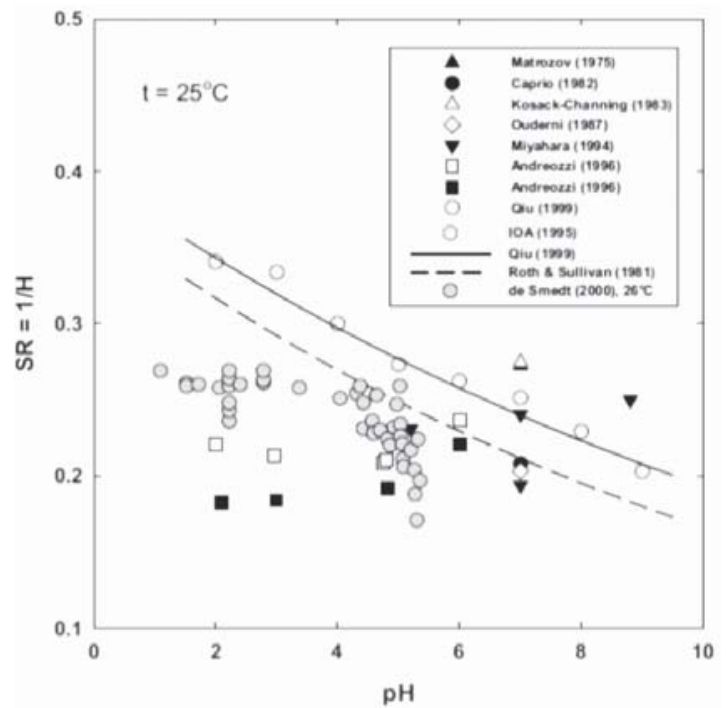

Figure 1-Effect of pH on ozone solubility ratio (SR=1/H) $(\mathrm{Bin}, 2006)$

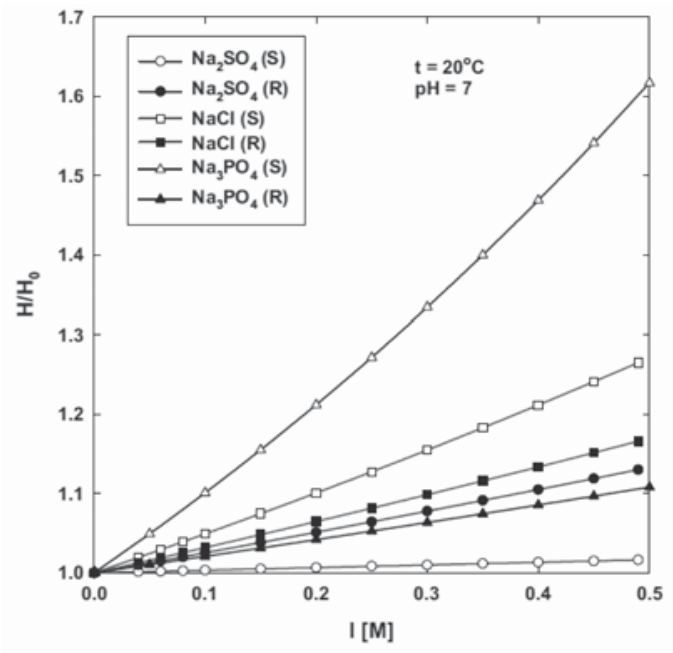

Figure 2-Effect of ionic strength on the ratio of Henry's Law constants in salt solutions $(\mathrm{H})$ and in water $(\mathrm{HO})(\mathrm{Bin}, 2006)$

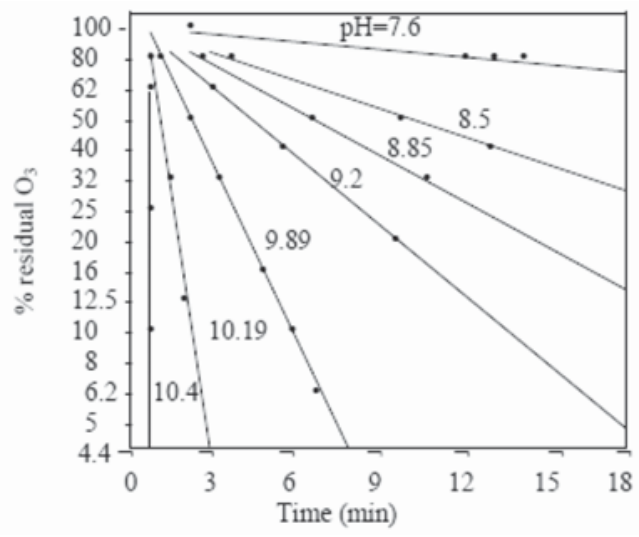

Figure 3-Effect of $\mathrm{pH}$ on the decomposition of ozone at $15^{\circ} \mathrm{C}$ (Grima, 2009)

common problem associated with ozonation (especially in laboratory-scale oxidation tests) is the poor mass transfer of ozone into the aqueous phase and the loss of ozone to the overlying headspace. In practical applications, ozone passing through the solution does not have sufficient contact time to reach equilibrium conditions, thereby resulting in lower solubilities than predicted from Henry's Law (Barlow, n.d.).

Additionally, the size of the gas bubbles has a significant effect on ozone distribution between the gas and liquid phases as well as its solubility. Large bubbles cause poor distribution since they tend to rise to the surface rapidly and release the ozone-air mixture into the headspace, whereas smaller bubbles promote intimate mixing and better lateral distribution through the saturated zone (Kollmeier, 2002).

The following parameters can affect the size of gas bubbles and therefore ozone dissolution (OzoneLab ${ }^{\mathrm{TM}}$ Instruments, n.d.):

> Type of gas-introducing system

> Type of impeller

> Agitation speed

$>$ Gas flow rate. 


\section{Evaluation of ozonation technology for gold recovery and cyanide management}

Usually, higher gas flow rates increase the mass transfer coefficient and the amount of soluble ozone. However, increasing the volume of the carrier gas $\left(\mathrm{O}_{2}\right.$ or air) may result in the formation of larger bubbles which have poorer diffusion characteristics. An increase in mixing rate influences the gas-liquid transfer positively (RodríguezRodríguez, 2014).

\section{Experimental approach}

\section{Chemical analysis}

The feed material was analysed for Au by standard fire assay, with $\mathrm{Au}$ finish using atomic absorption spectrometry (AAS) with a detection limit of $0.001 \mathrm{~g} / \mathrm{t}$. Base metals and Si were determined by inductively coupled plasma-optical emission spectrometry (ICP-OES) with a detection limit of $0.05 \%$. Additionally, S and C speciation were determined by a combustion technique with detection limits $0.01-0.2 \%$ (depending on the species analysed).

\section{Mineralogical analysis}

A portion of the feed material was pulverized and subjected to X-ray diffraction (XRD) analysis to identify the crystalline phases present and to determine their relative abundance. It should be noted that amorphous phases cannot be identified by this technique, and only crystalline phases present in amounts greater than approximately 3 mass\% are usually detectable.

Polished sections were prepared from a further portion of the feed material for bulk mineralogy, base metal sulphides (BMS) search, and for the gold deportment study on an automated scanning electron microscope (AutoSEM).

\section{Diagnostic leach procedure}

The diagnostic leach procedure involved the sequential dissolution of minerals associated with $\mathrm{Au}$, commencing with the least stable, and then extracting the associated $\mathrm{Au}$ by cyanidation/resin-in-leach (RIL). The test conditions are specified in Table I.

\section{Ozonation set-up}

The experimental set-up consisted of a $2 \mathrm{~L}$ glass baffled reactor, stirred mechanically with a slanted blade impeller. The reactor was equipped with electrodes for $\mathrm{pH}$ and $\mathrm{Eh}$ measurements. Ozone was produced from oxygen with a CD 2000P ozonator; the gas was fed into the reactor through a borosilicate glass sparger with a sintered filter candle with a porosity of four $(10-16 \mu \mathrm{m})$. The concentration of ozone in the gas outlet was determined by a BMT 964 ozone analyser.

All tests were conducted at the following conditions:

> Oxygen pressure of $10 \mathrm{psi}(68.9 \mathrm{kPa})$

> Oxygen flow rate of $10 \mathrm{cfh}$ or $283 \mathrm{~L} / \mathrm{h}$

> Ozone concentration in the inlet gas (read off the BMT analyser) an average $40 \mathrm{~g} / \mathrm{Nm}^{3}$, which corresponded to an ozone output of $19 \mathrm{~g} / \mathrm{h}$

> Agitation speed controlled at $400 \mathrm{r} / \mathrm{min}$.

\section{Pre-treatment of the ore}

Eight tests were conducted to evaluate the effect of $\mathrm{pH}$, Eh, temperature, and oxidation time on pre-oxidation efficiency of the gold ore. Pre-treatment was conducted at 30\% solids. Operating parameters such as Eh and ozone concentration in the gas phase were monitored. The test $\mathrm{pH}$ was adjusted to the required value by the addition of sulphuric acid.

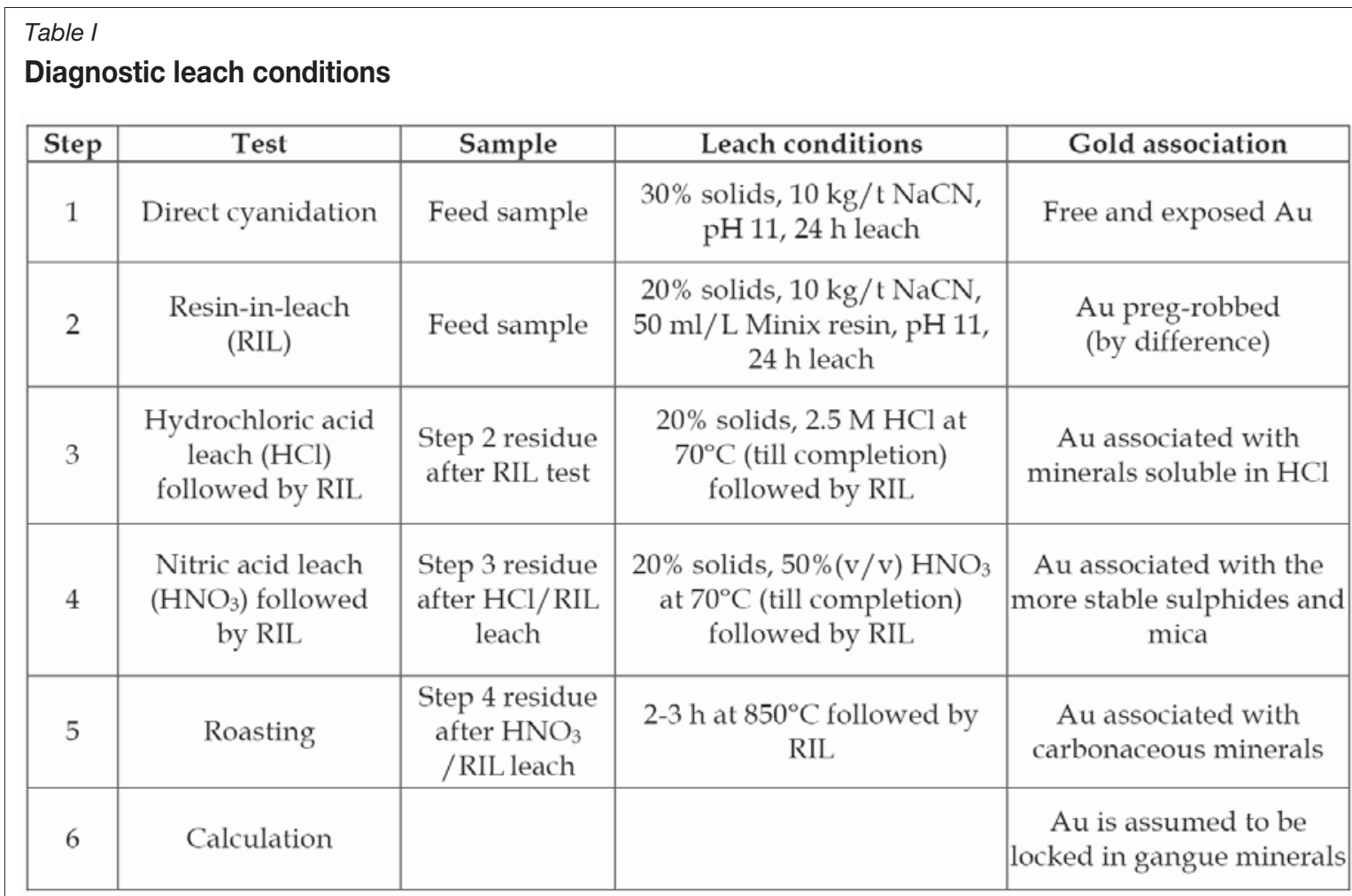




\section{Evaluation of ozonation technology for gold recovery and cyanide management}

\section{Cyanidation/RIL}

A sub-sample of the ore ('as is' or pre-treated with ozone) was slurried to $30 \%(\mathrm{~m} / \mathrm{m})$ solids using Rand Water Board water. The $\mathrm{pH}$ of the slurry was adjusted to 10.5 by the addition of dry hydrated lime (AR grade). Exactly $2 \mathrm{~kg} / \mathrm{t}$ sodium cyanide and $50 \mathrm{~mL} / \mathrm{L}$ of the Minix ${ }^{\circledR}$ resin (in the case of RIL) were added. After 24 hours' residence time, the resin was screened, the slurry was filtered, and the solids were washed three times by re-pulping with deionized water, dried, and subjected to gold analysis by fire assay. The resin was eluted with $20 \mathrm{BV}$ of acidic thiourea solution (1 M TU in $1 \mathrm{M} \mathrm{HCl}$ ) at $60^{\circ} \mathrm{C}$ and the eluates analysed for $\mathrm{Au}$ by AAS with detection limit of $0.08 \mathrm{mg} / \mathrm{L}$.

\section{Detoxification}

Test work was conducted on a sample of the slurry and filtrate generated during cyanidation of the sample. $1 \mathrm{~L}$ slurry and $700 \mathrm{~mL}$ solution were used for the test work. The filtrate contained $500 \mathrm{mg} / \mathrm{L} \mathrm{WAD} \mathrm{CN}$ and $350 \mathrm{mg} / \mathrm{L} \mathrm{SCN}$. The $\mathrm{pH}$ of the sample was maintained at a value of 10.5 by the addition of $1 \mathrm{M} \mathrm{NaOH}$ and the samples were treated with ozone. Solutions were analysed for $\mathrm{CN}$ species using segmented flow injection analysis (SFIA).

\section{Cyanide regeneration}

Three tests were done at different $\mathrm{pH}$ values. The test work was done on the PLS generated during cyanidation of the sample pre-oxidized with ozone at pH 2. A $350 \mathrm{~mL}$ sample of the liquor containing $1500 \mathrm{mg} / \mathrm{L} \mathrm{SCN}$ was acidified to $\mathrm{pH}$ values of 2, 3, and 4 prior to ozonation. Agitation was very slow to minimize liberation of HCN gas. The solutions were sparged with ozone and analysed for $\mathrm{CN}$ species using SFIA.

\section{Results}

\section{Sample characterization}

A sample of the double refractory ore originating from a greenstone belt in South Africa was used for this study. The sample was milled to $80 \%-75 \mu \mathrm{m}$ and the gold content

\section{Table II \\ Chemical composition of the sample}

\begin{tabular}{l|c|}
\hline Constituent & Value, \% $\mathrm{m} / \mathrm{m}$ \\
\hline $\mathrm{Mg}$ & 2.24 \\
$\mathrm{Al}$ & 3.27 \\
$\mathrm{Si}$ & 23.00 \\
$\mathrm{Ca}$ & 3.39 \\
$\mathrm{Ti}$ & 0.15 \\
$\mathrm{Fe}$ & 14.7 \\
$\mathrm{Zn}$ & 0.11 \\
$\mathrm{Cr}$ & 0.052 \\
$\mathrm{Mn}$ & 0.36 \\
As & 0.30 \\
Sulphide & 4.17 \\
Sulphate & 4.90 \\
Elemental S & 0.13 \\
Carbonate & 11.92 \\
Organic C & 1.12 \\
Au & $3.03 \mathrm{~g} / \mathrm{t}$ \\
\hline
\end{tabular}

determined in triplicate by fire assay at $3.03 \mathrm{~g} / \mathrm{t}$. The sample contained a significant amount of sulphides $(4.17 \%)$ and $1.12 \%$ organic carbon, which can contribute to refractoriness through preg-robbing.

The chemical analysis of the sample is listed in Table II, and Figure 4 presents the bulk modal mineralogical analysis.

The bulk modal analysis presented in Figure 4 indicated that the sample contained about $20 \%$ sulphide minerals, of which $15 \%$ was pyrrhotite (which can cause refractoriness of the ore), $54 \%$ silicates, $20 \%$ carbonates, and $1 \%$ organic carbon (potential preg-robber).

Gold in the ore was present as native gold (12 mass\%) and electrum (AuAg, 88 mass $\%$ ) with majority of particles within the 0-4 $\mu \mathrm{m}$ size class. Approximately $6 \%$ of the gold had free surface, while $82 \%$ was associated with pyrite, $5 \%$ with pyrrhotite, and $6 \%$ with silicate. From these results, the expected gold recovery via direct cyanidation of the ore was low.

The sample was subjected to a gold diagnostic leach, the main outcomes of which are presented graphically in Figure 5

The sample can be characterized as follows.

> Only $10 \%$ of the gold could be recovered via direct cyanidation

$>$ Addition of the resin to the cyanide leach increased the gold recovery to $23 \%$, indicating the presence of a preg-robbing component

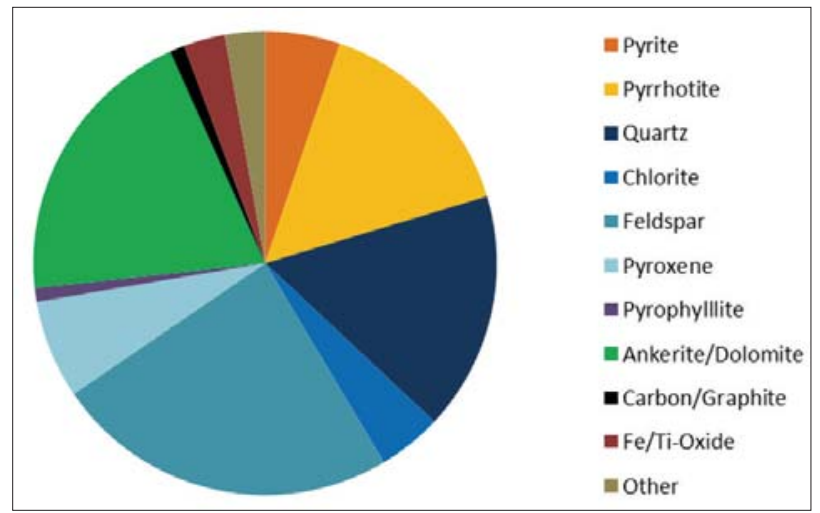

Figure 4-Mineralogical composition of the sample

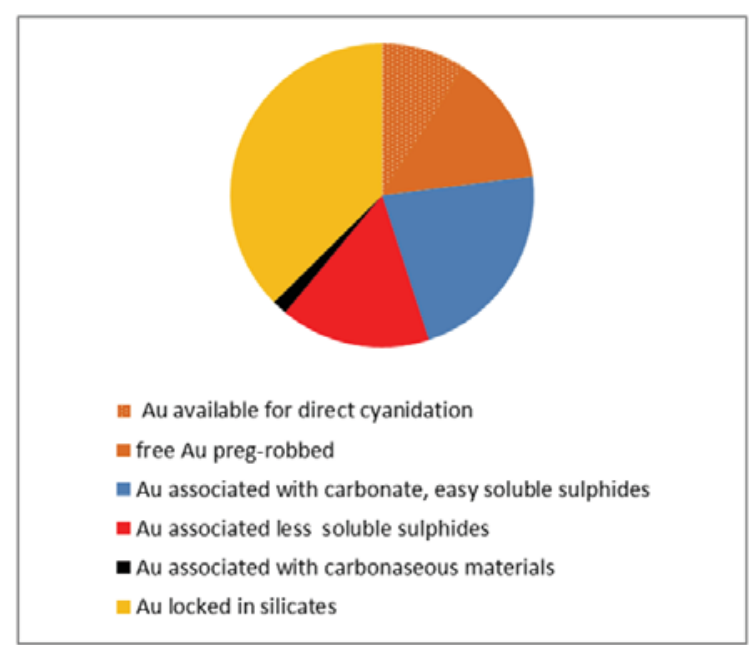

Figure 5-Gold association with different mineral phases 


\section{Evaluation of ozonation technology for gold recovery and cyanide management}

A significant portion of gold (22\%) was locked in carbonates and easily soluble sulphides

> Around $16 \%$ of the gold was recovered after treatment of the sample with $5 \mathrm{M} \mathrm{HNO}_{3}$ (this gold was associated with less soluble sulphide minerals)

> Roasting of the sample was targeted at the destruction of organic carbon in order to liberate gold associated with it. This fraction of the gold accounted for approximately $1.6 \%$ of the total gold present in the sample

> The rest of the gold in the sample (38\%) was not available for leaching and was probably locked in the silicate minerals.

\section{Ore pre-treatment via ozonation}

Eight pre-treatment tests were conducted at different conditions. The main outcomes are listed in Table III. Continuous acid addition was required to control the $\mathrm{pH}$ as the sample contained a significant amount of carbonates. Consequently, substantial amounts of $\mathrm{Mg}$ and $\mathrm{Ca}$ was leached, although $\mathrm{Ca}$ was simultaneously precipitated as gypsum for tests 1, 2, and 6-8. Additionally, relatively high amounts of $\mathrm{Fe}, \mathrm{Mg}, \mathrm{Mn}, \mathrm{Zn}$, and As were solubilized at $\mathrm{pH} \leq 3$.

At low $\mathrm{pH}$ values, oxidation of sulphides occurred according to the following reaction (González-Anaya, NavaAlonso, and Pecina-Treviño, 2011):

$$
2 \mathrm{FeS}_{2}+5 \mathrm{O}_{3}+2 \mathrm{H}_{2} \mathrm{O} \rightarrow 2 \mathrm{Fe}^{3+}+4 \mathrm{SO}_{4}{ }^{2-}+2 \mathrm{H}^{+}
$$

The mineralogical analysis of the leach residues (Figure 6) indicated that mostly pyrrhotite was leached, while pyrite was unreactive under the conditions tested.

For the tests conducted at pH 6 and 7, negligible amounts of $\mathrm{Ca}, \mathrm{Mg}$, and sulphate were detected in the solutions. At high $\mathrm{pH}$ very little or no carbonate dissolution was observed, and ferric ions produced from sulphide minerals according to Equation [5] were hydrolysed to form ferric hydroxide.

Test 5 , which was conducted at natural $\mathrm{pH}$, indicated that acid was generated during ozonation as the $\mathrm{pH}$ decreased from 7.6 to 7.1 after 60 minutes of ozonation, presumably due to the occurrence of reaction [5].

In order to evaluate the effects of pre-acidification and ozonation separately, test 6 was conducted at pH 2 but without ozone addition. Treatment with acid only resulted in similar or lower dissolutions of Fe, As, Zn, and Mn, with a significant portion of the pyrrhotite dissolving. It was noted that the acid consumption during pre-acidification was higher than in test 2, when ozone was added, i.e. $218 \mathrm{vs} 140 \mathrm{~kg} / \mathrm{t}$. The difference in acid consumptions proved that during ozonation, acid was generated by the oxidation of sulphides.

With an extended oxidation time and increased temperature applied during ozonation at $\mathrm{pH} 2$ (tests 7 and 8, respectively), the acid consumption, as well as the extraction of base metals and arsenic, increased.

\section{Gold recovery after pre-treatment}

The residues generated in the pre-oxidation experiments were subjected to cyanidation and resin-in-leach (RIL) tests

Table III
Extraction of the elements during pre-treatment
\begin{tabular}{|c|c|c|c|c|c|c|c|}
\hline \multirow{2}{*}{ Test } & Targeted $\mathrm{pH}$ & $\mathrm{H}_{2} \mathrm{SO}_{4}$ consumption, $\mathrm{kg} / \mathrm{t}$ & \multicolumn{5}{c|}{ Dissolution, $\%$} \\
\cline { 4 - 8 } & & 238 & 17 & 43 & 61 & 30 & 14 \\
\hline 1 & 1 & 140 & 16 & 33 & 51 & 32 & 20 \\
\hline 2 & 2 & 27 & 1 & 8 & 15 & 17 & 0 \\
\hline 3 & 3 & 4.4 & 0 & 2 & 0 & 3 & 0 \\
\hline 4 & 6 & 0 & 0 & 1 & 0 & 0 & 0 \\
\hline 5 & Natural $(7)$ & 218 & 17 & 48 & 64 & 11 & 2 \\
\hline 6 & $2\left(\mathrm{no} \mathrm{O}_{3}\right)$ & 160 & 21 & 45 & 62 & 34 & 31 \\
\hline 7 & $2(180 \mathrm{~min})$ & 212 & 28 & 62 & 87 & 65 & 47 \\
\hline 8 & $2\left(240 \mathrm{~min}, 45^{\circ} \mathrm{C}\right)$ & & & & & & \\
\hline
\end{tabular}

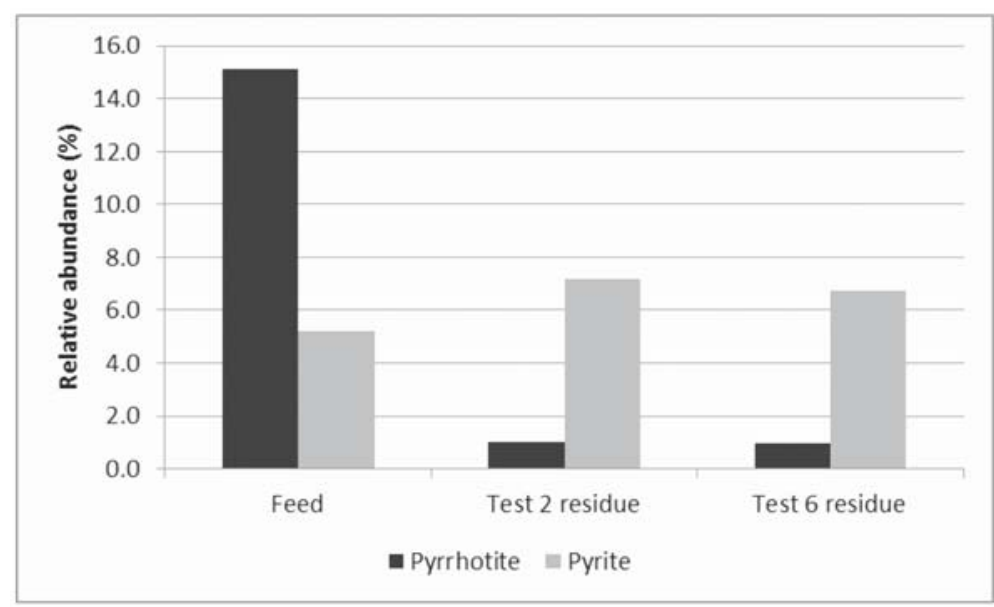

Figure 6-Effect of pre-treatment of sulphide minerals in the sample 


\section{Evaluation of ozonation technology for gold recovery and cyanide management}

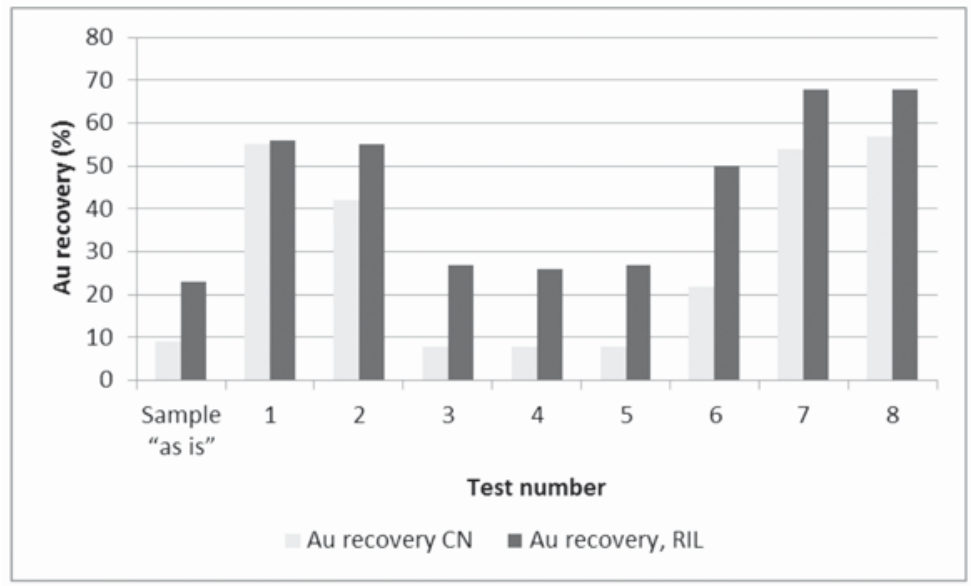

Figure 7-Effect of pre-treatment on recovery of gold

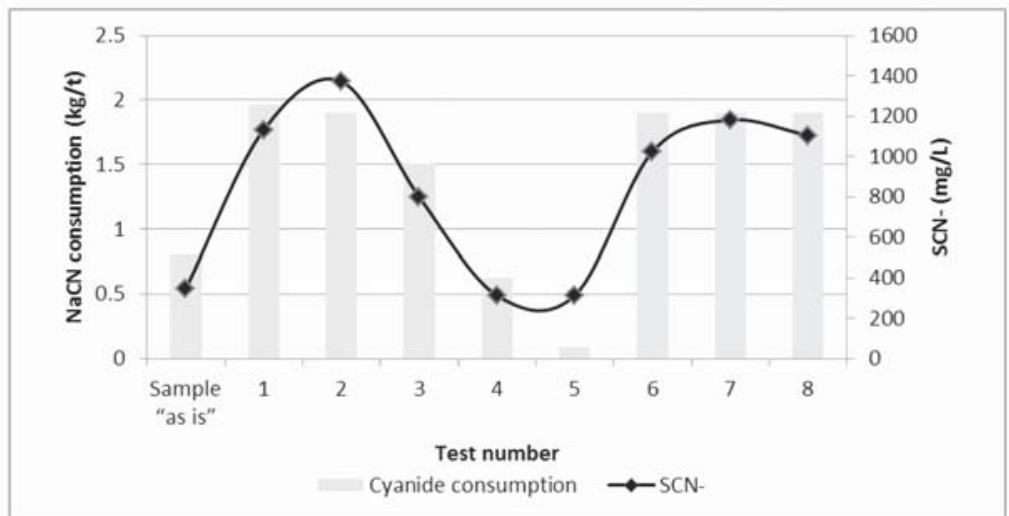

Figure 8-Cyanide consumption and thiocyanate formation during cyanidation

to evaluate the effect of ozonation on subsequent gold recovery. Figure 7 shows the results of these tests.

Pre-oxidation with ozone at $\mathrm{pH} 1$ and 2 improved gold recoveries via cyanidation significantly, from $9 \%$ to $42-55 \%$. Moreover, after pre-treatment at $\mathrm{pH} 1$ subsequent cyanidation and RIL tests resulted in similar gold recovery values, indicating that ozonation destroyed the preg-robbing component in the ore. Pre-oxidation at $\mathrm{pH} 3$ and above did not result in improved gold extraction, probably due to the formation of a passivating layer of ferric hydroxide on the surface of the sulphide minerals, which prevented further oxidation of sulphides and liberation of gold.

Pre-acidification to $\mathrm{pH} 2$ (test 6) prior to cyanidation resulted in increased Au recovery via cyanidation as well as RIL ( $22 \%$ and $50 \%$ respectively) compared to the sample 'as is'. However, the improvement in gold recovery was lower than for test 2 (ozone was added at pH 2). An extended ozonation time improved $\mathrm{Au}$ extraction even further (tests 7 and 8).

\section{Reagent consumptions and thiocyanate formation after ozonation}

Cyanide added to the slurries could be consumed by sulphur species (reactive sulphide minerals and some possible intermediate products of sulphide oxidation such as elemental sulphur and thiosulphate) with the formation of thiocyanate as per the equations below (Gok, 2010)

$$
\mathrm{Fe}_{7} \mathrm{~S}_{8}+\mathrm{CN}^{-} \rightarrow 7 \mathrm{FeS}+\mathrm{SCN}^{-}
$$

$\mathrm{FeS}_{2}+4 \mathrm{CN}^{-}+3 \mathrm{O}_{2}+6 \mathrm{H}_{2} \mathrm{O} \rightarrow 4 \mathrm{Fe}(\mathrm{OH})_{3}+4 \mathrm{SCN}^{-}$

$\mathrm{S}^{\circ}+\mathrm{CN}^{-} \rightarrow \mathrm{SCN}^{-}$

$\mathrm{S}_{2} \mathrm{O}_{3}{ }^{2-}+\mathrm{CN}-\rightarrow \mathrm{SCN}-+\mathrm{SO}_{3}{ }^{2-}$

$\mathrm{S}_{4} \mathrm{O}_{6}{ }^{2-}+\mathrm{CN}^{-} \rightarrow 2 \mathrm{SCN}^{-}+2 \mathrm{SO}_{3}{ }^{2-}$

Figure 8 shows the thiocyanate concentrations formed in the leach liquors and corresponding cyanide consumption during the various tests.

During direct cyanidation of the 'as is' sample, a cyanide consumption of $0.8 \mathrm{~kg} / \mathrm{t}$ was reported, which is probably attributable to reaction with highly reactive sulphides. Pretreatment conducted at low $\mathrm{pH}$ values $(\leq 3)$ resulted in increased cyanide consumptions, presumably due to additional liberation of pyrite particles after carbonates and pyrrhotite were dissolved and/or intermediate products of sulphide oxidation were formed during ozonation.

It was expected that an extended oxidation time or increased temperature would improve the extent of oxidation of sulphur species to sulphate and minimize cyanide consumption downstream. Nevertheless, additional tests conducted (tests 7 and 8) for prolonged oxidation times did not decrease the subsequent cyanide consumption. 


\section{Evaluation of ozonation technology for gold recovery and cyanide management}

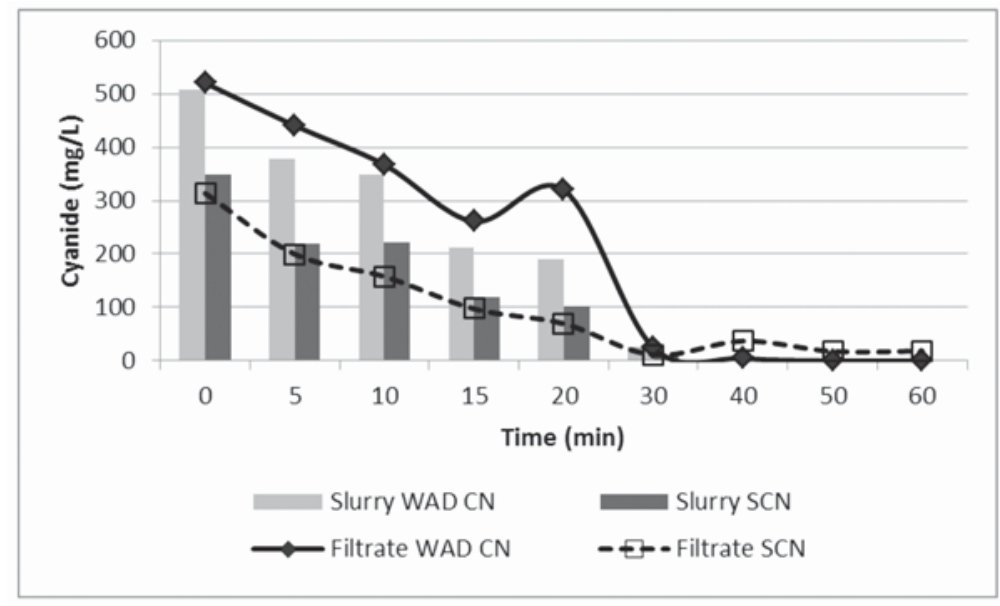

Figure 9-Kinetics of cyanide detoxification

However, a decrease in subsequent cyanide consumption was observed after pre-oxidation within the higher $\mathrm{pH}$ range (between 6 and 8). A similar trend was observed by CarrilloPedroza and Salinas-Rodríguez (2012). The decrease in cyanide consumption and $\mathrm{SCN}^{-}$formation was attributed to the formation of ferric hydroxide on the surface of the sulphides during oxidation, which inhibited further dissolution of the sulphide minerals.

\section{Cyanide detoxification}

The tailings from the cyanidation tests were subjected to cyanide detoxification tests. The filtrate contained $500 \mathrm{mg} / \mathrm{L}$ WAD CN and $350 \mathrm{mg} / \mathrm{L} \mathrm{SCN}^{-}$. No SAD CN was detected in the samples. Detoxification was done at $\mathrm{pH}$ of 10.5. At a high $\mathrm{pH}$ and excessive ozone addition, the following reactions would be expected to take place (Parga, Shukla, and CarrilloPedroza, 2003):

$$
\begin{aligned}
& \mathrm{O}_{3}+\mathrm{CN}-\rightarrow \mathrm{OCN}-+\mathrm{O}_{2} \\
& \mathrm{SCN}+2 \mathrm{O}_{3}+\mathrm{H}_{2} \mathrm{O} \rightarrow \mathrm{SO}_{4}{ }^{2-}+\mathrm{CNO}^{-}+\mathrm{O}_{2}+2 \mathrm{H}^{+} \\
& 2 \mathrm{CNO}^{-}+3 \mathrm{O}_{3}+\mathrm{H}_{2} \mathrm{O} \rightarrow 2 \mathrm{HCO}_{3}^{-}+\mathrm{N}_{2}+3 \mathrm{O}_{2}
\end{aligned}
$$

The thiocyanate and WAD cyanide concentration profiles in the slurry and filtrate samples achieved during the tests are presented in Figure 9.

Similar rates of $\mathrm{CN}^{-}$and $\mathrm{SCN}^{-}$detoxification were observed in both the slurry and filtrate samples. After 30 minutes of ozonation, more than $90 \%$ of $\mathrm{CN}^{-}$and $\mathrm{SCN}^{-}$ anions were destroyed. Complete destruction of cyanide down to $<1 \mathrm{mg} / \mathrm{L}$ was achieved within 50 minutes of ozonation. The residual thiocyanate concentrations in the slurry and filtrate samples were 2 and $15 \mathrm{mg} / \mathrm{L}$, respectively.

\section{Cyanide regeneration}

In an acidic medium cyanide exists mainly as hydrocyanic acid, which is less amenable to oxidation, while thiocyanate oxidation occurs at various $\mathrm{pH}$ values (Nava, Uribe, and Pérez, 2003). Cyanide can be regenerated from thiocyanate via ozonation at low $\mathrm{pH}$ according to the following reaction:

$$
\mathrm{SCN}^{-}+\mathrm{O}_{3}+\mathrm{H}_{2} \mathrm{O} \rightarrow \mathrm{SO}_{4}^{2-}+\mathrm{HCN}+\mathrm{H}^{+}
$$

In order to identify the optimum conditions for thiocyanate conversion to $\mathrm{HCN}$ with minimal subsequent cyanide oxidation, three tests were conducted on the filtrate obtained from cyanidation of the residue generated after preoxidization of the sample at $\mathrm{pH} 2$. The cyanide leach liquor, containing $1500 \mathrm{mg} / \mathrm{L} \mathrm{SCN}^{-}$, was acidified to $\mathrm{pH}$ values of 2 , 3 , and 4 prior to further ozonation.

Figure 10 illustrates the efficiency of thiocyanate oxidation (in terms of fractional oxidation: $\frac{C_{0}-C}{C_{0}}, \%$ ) and the cyanide yield $v s$ time.

It was found that cyanide regeneration from thiocyanate was most efficient at $\mathrm{pH} 2$. After 40 minutes of ozonation, approximately $85 \%$ of the thiocyanate was oxidized to cyanide with a yield of $60 \%$. Although oxidation of thiocyanate continued further to $<10 \mathrm{mg} / \mathrm{L} \mathrm{SCN}^{-}$in solution, the cyanide concentration actually started to decrease. This could be attributed to either oxidation of cyanide by ozone or (most probably) liberation as HCN gas at this $\mathrm{pH}$ value.

At $\mathrm{pH}>3$ oxidation/conversion of thiocyanate was slower and thus after 90 minutes of ozonation the residual $\mathrm{SCN}^{-}$ concentration in the solution was $174 \mathrm{mg} / \mathrm{L}$. The maximal efficiency of cyanide production was about $48 \%$. At pH 4 , oxidation of thiocyanate was rapid. However, only a $16 \%$ cyanide yield was achieved after 5 minutes of ozonation. Any cyanide formed further was oxidized quickly.

\section{Potential for implementation of ozonation at different stages of gold processing}

As shown in Figure 11, in the case of the sample studied, ozonation technology has a good potential for application at different stages of gold processing. It improved the overall gold recovery and showed a high potential for the minimization of environmental impact associated with cyanidation. Moreover, regeneration of cyanide consumed by sulphur species could provide additional benefits with regard to OPEX.

There is a need to evaluate alternative options for the processing of this specific sample and provide direct OPEX and CAPEX comparisons in order to account fully for all the benefits of ozonation technology.

\section{Conclusions}

The evaluation of ozonation technology for treatment of a 


\section{Evaluation of ozonation technology for gold recovery and cyanide management}

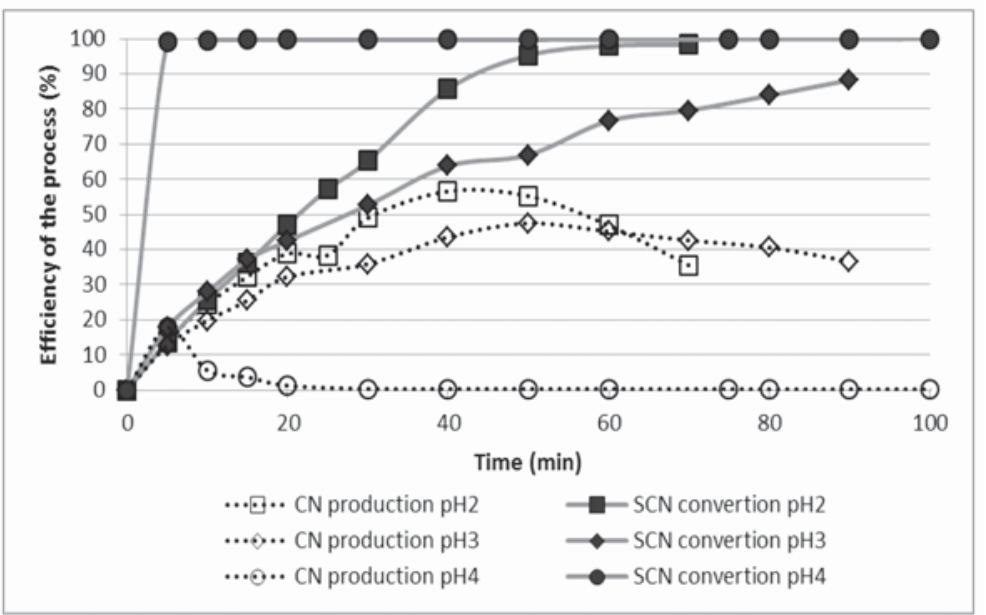

Figure 10-Cyanide regeneration from thiocyanate

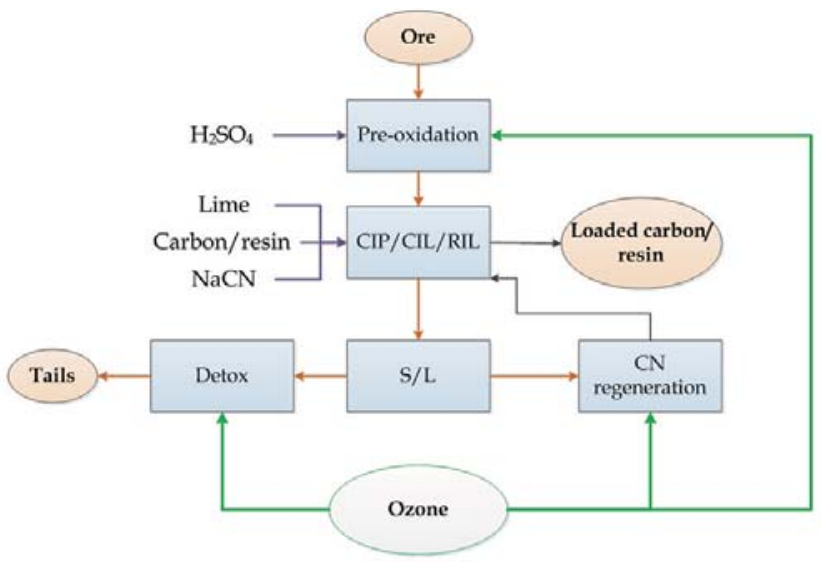

Figure 11-Flow sheet for treatment of refractory ore with ozonation implemented

double refractory ore sample indicated that it could be successfully applied for different stages of the gold recovery process.

Pre-treatment of the material after acidification to $\mathrm{pH} 1-2$ via ozonation resulted in significantly improved gold recoveries during subsequent cyanidation, from $25 \%$ to 60 $70 \%$. Treatment of the sample with ozone in the $\mathrm{pH}$ range of 1 to 4 resulted in increased cyanide consumptions (from 0.8 $\mathrm{kg} / \mathrm{t}$ to $1.9 \mathrm{~kg} / \mathrm{t}$ ) due to the formation of thiocyanates. Ozonation of the sample at pH 1 and 2 caused partial destruction of preg-robbing component. Ozonation at pH 6-8 did not improve gold recovery, but did result in reduced cyanide consumptions compared to the 'as is' sample.

Tests on detoxification of the cyanide/thiocyanatecontaining gold leach slurry and filtrate $(\mathrm{pH} \mathrm{10.5)} \mathrm{via}$ ozonation confirmed that ozone was an efficient oxidant for both the cyanide and thiocyanate species. More than $99 \%$ of $\mathrm{CN}^{-}$and $\mathrm{SCN}^{-}$were destroyed after 30 minutes of ozonation.

The regeneration of cyanide consumed by sulphur species with the formation of thiocyanate via ozonation at low $\mathrm{pH}$ values was found to be promising enough to warrant further investigations. At pH 2,60\% of thiocyanate was converted to cyanide after 40 minutes of ozonation.

\section{References}

BarLow, P. Not dated. Lifelineozone.

http://www.lifelineozone.com/research/ozone\%20basics/basic1.pdf [accessed 22 March 2016].

BIN, A.K. 2006. Ozone solubility in liquids. Ozone: Science and Engineering, vol. 28. pp. 67-75.

Bотz, M.D. 2001. Technologies for the regeneration of cyanide. Mineral and Metallurgical Processing, vol. 18, no. 3. pp. 126-132.

Carrillo-Pedroza, F.R-A. and Salinas-Rodríguez, E.M-L-T-S. 2012. Oxidative hydrometallurgy of sulphide minerals. Recent Researches in Metallurgical Engineering - From Extraction to Forming. Nusheh, M. (ed.). InTech. pp. 25-42.

ERSHov, B.M. 2009. The kinetics of ozone decomposition in water, the influence of $\mathrm{pH}$ and temperature. Russian Journal of Physical Chemistry and Electrochemistry. pp. 1295-1299.

Gок, O. 2010. Oxidative leaching of sulfide ores with the participation of nitrogen species - a review. Journal of Ore Dressing, vol. 12, no. 24. pp. 22-29.

GonzÁlez-Anaya, J., Nava-Alonso, F., and Pecina-Treviño, E. 2011. Use of ozone for gold extraction from highly refractory concentrate. Ozone: Science and Engineering, vol. 33, no. 1. pp. 42-49.

GRIMA, N. 2009. Kinetic and mass transfer studies of ozone. PhD thesis, School of Engineering Design \& Technology, University of Bradford, UK. https://bradscholars.brad.ac.uk/bitstream/handle/10454/3351/Thesis\%20 -\%20May\%202009.pdf?sequence=2 [accessed 15 March 2016].

KHONGKitTiKHoon, W., LeRdLATTAPorn, R., Nopharatana, M., and SongKasiri, W. 2011. Cyanide removal by ozone oxidation in tapioca starch industrial wastewater for recycling purposes: effects of $\mathrm{pH}$ and starch concentration. Asian Journal of Food and Agro-Industry, vol. 4, no. 5. pp. 286-296.

KOLLMEIER, J.A. 2002. In-situ MTBE remediation using air sparging augmented by ozone. National Ground Water Association, Westerville, Ohio.

LANGLAIS, B. R. 1991. Ozone in Water Treatment: Application and Engineering. Lewis Publishers, Boca Raton, FL

LENNTECH, B.V. 1998. Ozone generation. http://www.lenntech.com/library/ozone/transfer/ozone-transfermechanisms.htm [accessed 22 March 2016].

LoEB, B. 2011. Ozone: Science \& Engineering: thirty-three years and growing. Ozone Science \& Engineering, vol. 33, no. 4. pp. 329-342.

LURJE, J. 1971. Handbook of Analytical Chemistry. Science, Moscow.

NAVA, F., URibE, A., and PÉrez, R. 2003. Use of ozone in the treatment of cyanide containing effluents. European Journal of Mineral Processing and Environmental Protection, vol. 3, no. 3. pp. 316-323.

OzoneLAB ${ }^{\text {TM }}$ InSTRUMENTS. Not dated. What determines the final levels of ozone in water? http://www.ozoneservices.com/faq/faq024.htm [accessed 17 March 2016].

Parga, J., Shukla, S., and Carrillo-Pedroza, F. 2003. Destruction of cyanide waste solutions using chlorine dioxide, ozone and titania sol. Waste Management, vol. 23, no. 2. pp. 183-191.

RodríGuez-RodríGuez, C. N-A-S. 2014. Silver leaching from pyrargyrite oxidation by ozone in acid media. Hydrometallurgy, vol. 149. pp. 168-176. 